\title{
Relationship Stressors with Stress and Student Learning Achievement (Coss Sectional Study at STIKES Nani Hasanuddin Makassar)
}

\author{
Rezki Yalatri Wirastuty a, 1 \\ a Pharmacy Program of Graduate School, Universitas Hasanuddin, Indonesia \\ ${ }^{1}$ reskiyalatri89@gmail.com
}

\begin{abstract}
Physical environmental stressor, psychological, environmental stressor, and burden in learnings are representing the source stress student can reside at stress condition. Stress realized by the student would influence the learning process so it will affect learning achievement. This study was aimed to explain the relation of stressor student by stress and learn achievement in STIKES Nani Hasanuddin Makassar. The design used in this study was the cross-sectional design. The sample consisted of 113 respondent, taken from the students of DIII Pharmacy STIKES Nani Hasanuddin Makassar Semester III and V. Sample was taken using by purposive sampling. Data gathered were Analyzed by Spearman Rho Tests with significant level $p<0,05$. Result showed that relation of student stressor with stress was $(p=0,000)$ and relation of student stressor with learn achievement $(p=0,000)$. This result was an indication that there was a relation between student stressor with stress and stressor student with learning achievement. It can be concluded that student stressor has a correlation with student stress and learn achievement. If student stressor accepted increasing so, student stress would increase, and progressively lower the stressor accepted it would increase learn achievement. Some things that can be done is the improvement of learning facilities and creating a conducive environment.
\end{abstract}

Keywords

Stressor; Stress; Learning Achievement

\section{INTRODUCTION}

To create a very precise pharmacy partnership requires good teaching and learning costs and excellent facilities as well. Stress experienced by students significantly affect the teaching and learning process of students. This condition resulted in the reduced ability of students in studying and understanding the lecture materials that have been given. The lack of retention will affect student achievement which can be recognized by understanding achievement indicator Index that is not satisfactory. If this continues, the student may fall in frustration. 
Stress is widely known as a major challenge in realizing good behavior. Someone who was experiencing stress, usually experiencing health problems and have a low motivation that will impact on individual performance (Putra, 2012). Stress is a manifestation of the emergence of a stressor, where the impact of stressors depends on the nature of the stressor, the number of stressors, the duration of exposure to stressors, past experiences, and developmental levels (Erb, 1983). One can experience stressful conditions starting from the first (lightest) stage, the second stage, the third stage, the fourth stage, the fifth stage, the sixth stage (the heaviest) (Dadang, 2001).

The existence of a demand to solve the problems and stressful situations (stressor) is a trigger emergence of a set of ways from individuals to deal with it where the method the individual faces a stressful situation is called the king process (Niam, 2009).

Therefore, this study was conducted to determine the relationship between student stressors with stress and achievement of learning in the students of the third semester and $V$ of the academic year 2014-2015 DIII Pharmacy STIKES Nani Hasanuddin Makassar.

\section{RESEARCH METHOD}

This research was conducted from January to March 2015 at STIKES Nani Hasanuddin Makassar. In this research, the researcher uses purposive sampling technique that is a technique of determining the sample by selecting the sample among the population according to the desired researcher.

Population in this research is Pharmacy student of STIKES Nani Hasanuddin Makassar of the academic year 2015-2016 which amounted to 158 students. The sample size in this research is 113 students.

\section{RESULT AND DISCUSSION}

\section{General Data}

In the academic year 2014 - 2015 the students DIII Pharmacy STIKES Nani Hasanuddin Makassar as many as 257 students, consisting of 99 students level I, 98 students of second grade and 83 students. Clearly, the distribution of students can be seen in Figure 1. 


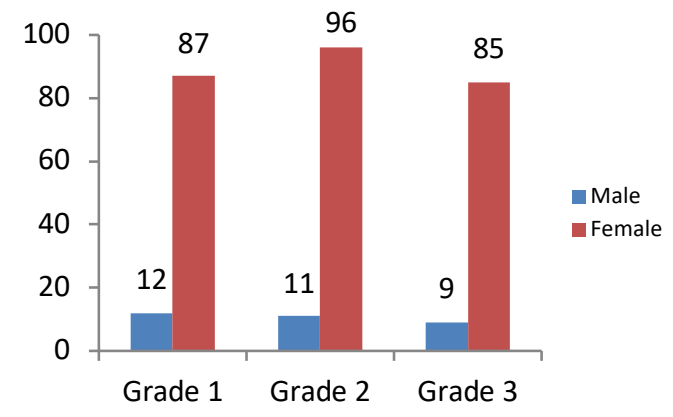

Figure 1. Distribution number of students

\section{Characteristics of Respondents}

Age of Respondent

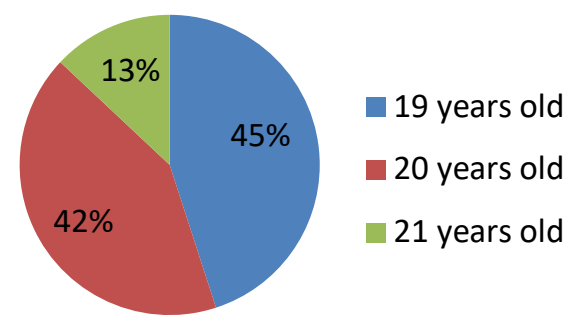

Figure 2. Percentage distribution by age

Figure 2 shows that most respondents of second and third grade students DIII Pharmacy STIKES Nani Hasanuddin is 19 years old $(45 \%)$, while the age of other respondents is 20 years (42\%) and age 21 years $(13 \%)$.

Sex of Respondent

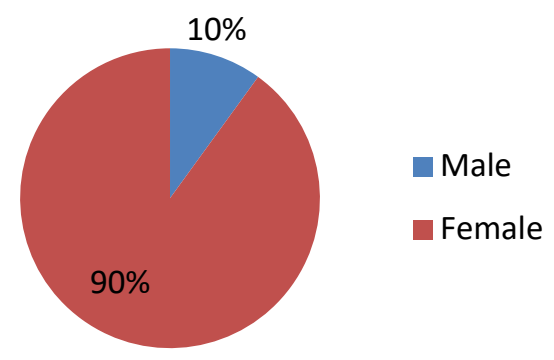

Figure 3. Percentage distribution by sex
Figure 3 shows that most respondents by sex of second and third grade students DIII Pharmacy STIKES Nani Hasanuddin Makassar is female (90\%), while male respondents (10\%).

\section{Research Variables}

\section{Student Stressors}

Table 1. Distribution of stressor frequency of student on level II and III.

\begin{tabular}{|c|l|c|c|}
\hline No & $\begin{array}{l}\text { Student } \\
\text { Stress }\end{array}$ & Frequency & $\begin{array}{c}\text { Percentage } \\
(\%)\end{array}$ \\
\hline 1 & Light & 9 & 8.0 \\
2 & Medium & 92 & 81.4 \\
3 & Weight & 12 & 10.6 \\
\hline & Total & 113 & 100 \\
\hline
\end{tabular}

As shown in Table 1, the stressors experienced by students include mild (8.0\%), moderate (81.4\%) and weight $(10.6 \%)$. This data shows that most of the stressors experienced by respondents are moderate stressors $92 \quad(81.4 \%)$ of respondents.

Table 2. Distribution of student stressor frequency based on each indicator of student level II and level III.

\begin{tabular}{|c|l|c|c|c|c|c|c|}
\hline No & \multicolumn{1}{|c|}{ Indicator } & Weight & $\%$ & Medium & $\%$ & Light & $\%$ \\
\hline 1 & $\begin{array}{l}\text { Physical } \\
\text { environment } \\
\text { londitions }\end{array}$ & 2 & 2.7 & 38 & 50.7 & 35 & 46.7 \\
\hline 2 & $\begin{array}{l}\text { Social } \\
\text { environment } \\
\text { condition }\end{array}$ & 2 & 2.7 & 22 & 29.3 & 51 & 68.0 \\
\hline 3 & Loads of study & 3 & 4.0 & 25 & 33.3 & 47 & 62.7 \\
\hline
\end{tabular}

Table 2 shows some indicators of stressors experienced by students at all 
levels ranging from mild to severe who experience them. For the indicator of physical environment condition, most respondent $38(50.7 \%)$ stated that the level of stress is moderate, while for sign of social environment condition most of respondent 51 (68,0\%) expressing lightness level and for the indicator of study load most respondent 47 (62.7\%) states mild stress levels.

\section{Student Stress}

Table 3. Distribution of stress frequency of respondent level II and level III.

\begin{tabular}{|c|l|c|c|}
\hline No & $\begin{array}{c}\text { Student } \\
\text { Stress }\end{array}$ & Frequency & $\begin{array}{c}\text { Percentage } \\
(\%)\end{array}$ \\
\hline 1 & Light & 12 & 10.6 \\
2 & Medium & 90 & 79.7 \\
3 & Weight & 11 & 97 \\
\hline & Total & 113 & 100 \\
\hline
\end{tabular}

Table 3 shows that the stresses experienced by students include mild (10.6\%), moderate $(79.7 \%)$ and weight (9.7\%). These data indicate that the stress experienced by students is a moderate level of stress (79.7\%).

Table 4. Distribution of stress frequency of respondents based on each stress indicator on the students of level II and level III.

\begin{tabular}{|c|l|c|c|c|c|c|c|}
\hline No & Indicator & Weight & $\%$ & Medium & $\%$ & Light & $\%$ \\
\hline 1 & $\begin{array}{l}\text { Physical } \\
\text { stress }\end{array}$ & 1 & 1.3 & 34 & 45.3 & 40 & 53.3 \\
\hline 2 & $\begin{array}{l}\text { Psychologica } \\
\text { I stress }\end{array}$ & & & 14 & 18.7 & 61 & 81.3 \\
\hline
\end{tabular}

In table 4 , it can be seen that in the physical stress indicator of most respondents is 40 (53.3\%) which stated mild stress level; 34 (45.3\%) respondents stated moderate stress level and $1(1.3 \%)$ respondent stated severe stress level. The highest indicators of psychological stress at most is $61(81.3 \%)$ respondents that belong to a mild stress level group, and 14 (18.7\%) respondents belong to a moderate stress level.

\section{Achievement Index}

Table 5. Frequency distribution of respondents' achievement index at second and third grade students.

\begin{tabular}{|c|l|c|c|}
\hline No & $\begin{array}{c}\text { Grade } \\
\text { Point }\end{array}$ & Frequency & $\begin{array}{c}\text { Percentage } \\
(\%)\end{array}$ \\
\hline 1 & Very good & 12 & 10.6 \\
2 & Good & 34 & 30.1 \\
3 & Enough & 59 & 52.2 \\
4 & Less & 8 & 7.1 \\
5 & Very less & 0 & 0 \\
\hline & Total & 113 & 100 \\
\hline
\end{tabular}

In table 5 student achievement index is very good $(10,6 \%)$, good $(30,1 \%)$, enough $(52,2 \%)$ and less $(7,1 \%)$. From these data indicate that most of the achievement index reached by respondents is enough 59 $(52,2 \%)$ of respondents.

Stressor Relationship with Stress 
Table 6. Distribution of stressor relationship with student stress level II and level III.

\begin{tabular}{|c|c|c|c|c|c|c|}
\hline $\begin{array}{l}\text { Stress } \\
\text { Stressor } \\
\end{array}$ & Light & $\%$ & Medium & $\%$ & Weight & $\%$ \\
\hline Light & 4 & $3.5 \%$ & 4 & $3.5 \%$ & 5 & $4.4 \%$ \\
\hline Medium & 5 & $4.4 \%$ & 79 & $70 \%$ & 7 & $6.2 \%$ \\
\hline Weight & & & 9 & $8 \%$ & & \\
\hline \multicolumn{7}{|c|}{$r=0.489$} \\
\hline \multicolumn{7}{|c|}{$p=0.000$} \\
\hline
\end{tabular}

In table 6, it can be seen that from 113 respondents who conducted the most research (70.0\%) respondents are in medium-level stress conditions caused by a moderate level of stressors. But there were no respondents with mild stress levels caused by severe stressors. There were (6.2\%) respondents with severe stress levels caused by severe stressors. Based on the above table it is known that there is a meaningful relationship between student stress with stress student DIII Pharmacy STIKES NaniHasanuddin Makassar force 2003 with $p=0.000$ and correlation coefficient level of moderate relationship with value $r=0.489$.

Stressor Relationship with Achievement Index
Table 7. Distribution of Stressor Relation with Student Achievement Index of Level II and Level III.

\begin{tabular}{|c|c|c|c|c|c|c|c|c|}
\hline $\begin{array}{c}\text { Grade Point } \\
\text { tressor }\end{array}$ & $\begin{array}{c}\text { Very } \\
\text { good }\end{array}$ & $\%$ & Good & $\%$ & Enough & $\%$ & Less & $\%$ \\
\hline Light & 3 & $2.6 \%$ & 4 & $3.5 \%$ & 3 & $2.6 \%$ & 3 & $2.6 \%$ \\
Medium & 9 & $8.0 \%$ & 28 & $24.8 \%$ & 48 & $42.5 \%$ & 5 & $4.4 \%$ \\
Weight & & & 2 & $1.8 \%$ & 8 & $7.1 \%$ & & \\
\hline \multicolumn{6}{c}{$r=0.462$} \\
$p=0.000$ \\
\hline
\end{tabular}

The results from the cross-tabulation in Table 7 show that at most 48 (42.5\%) respondents get a sufficient level of achievement index that is influenced by moderate stressors. There were also 9 (8.0\%) respondents got excellent achievement index with moderate stress level. Based on the above table it is known that there is a significant relationship between student stressors with student achievement index DIII Pharmacy STIKES Nani Hasanuddin Makassar academic year 2015-2016 with $p=0.000$ and correlation coefficient level of moderate relationship with value $r=0.462$.

\section{CONCLUSION}

Based on the results of research that has been done can be concluded as follows:

1. Most of the respondents stated that the stressors experienced by the students of DIII Pharmacy STIKES Nani Hasanuddin Makassar level 2 and 3 are at a 
moderate level, especially in the physical environment stressors that include facilities and infrastructure. While the second stressor is a stress load of learning that includes loss of concentration while learning, too many tasks and the burden of learning too much. The third stressors are social environment stressors that include tension in interacting with friends and being dependent on others and difficulty adapting to friends,

2. Most of the respondents stated that the stress experienced by the students of DIII Pharmacy STIKES Nani Hasanuddin Makassar level 2 and 3 are at a moderate level, especially in physical stress that includes sleep disturbances, headache, heartburn. The psychological stress that includes feelings of anxiety or fear, easy to forget while learning and easily confused.

3. The average respondent shows the achievement index achieved by the students DIII Pharmacy STIKES Nani Hasanuddin Makassar level 2 and 3 are in enough level.

4. There is a solid relationship between several indicators of stressors with some stress indicators. These include the relationship of physical environmental

stressors with physical stress; social environmental stressors with physical stress; social environmental stressors with psychological stress; stress of learning load with psychological stress; physical environmental stressors with index achievement; social environmental stressors with achievement index; and stress load study with achievement index.

There is no significant relationship between some stressors indicator with some stress indicator including physical environment stressors with psychological stress and stress load study with physical stress.

\section{RECOMMENDATION}

As for suggestion from the result of this research is that need to prepare our self to adapt to the physical environment, social environment and burden learn when entering college level.

\section{ACKNOWLEDGMENT}

Authors would like to thank Indonesia Endowment Fund for Education (LPDP) for financial support.

\section{REFERENCES}


Diponegoro, A. M., Thalib, S. B., (2001). Meta-Analisis Tentang Perilaku Koping Prevenstif dan Stres. Psikologika: Jurnal Pemikiran dan Penelitian Psikologi, 6.12, 51-62.

Hawari, Dadang. (2001). Manajemen Stres. Cemas, dan Depresi, Jakarta, Balai Penerbit FKUI

Kozier, Barbara. (2008). Fundamentals of nursing: concepts, process and practice. Pearson Education.

Niam, Erni Khoirun. (2009). Koping terhadap Stres pada Mahasiswa Luar Jawa yang Mengalami Culture Shock di Universitas Muhammadiyah Surakarta. Indigenous: Jurnal IImiah Psikologi

Notoatmojo. (2002). Metodologi Penelitian Kesehatan. Cetakan Kedua. Edisi Revisi. Jakarta. Salemba Medika

Putra, Yanuar Surya. (2012). Hubungan Antara Motivasi Belajar dan Sikap Mahasiswa STIE AMA Salatiga Dalam Perkuliahan Dengan Stress Sebagai Variabel Kontrol. Jurna IIImiah Among Makarti

Putri, Vedora Kusumanda Herdy. (2015). Hubungan antara Kemandirian dengan Stress Akademik pada Mahasiswa yang Merantau di Salatiga.
PhD Thesis. Program Studi Psikologi FPSI-UKSW.

Sardiman A. M. (2010). Interaksi dan Motivasi Belajar Mengajar. Jakarta: Raja Grafindo Persada.

Suwarno, dkk. (2006). Pengajaran Mikro Pendekatan Praktis dalam Menyiapkan Pendidik Profesional. Yogyakarta: Tiara Wacana

Wahid \& Nurul. (2008). Konsep Diri. Jakarta. EGC. 